\title{
Effect of Laserpuncture Shoot on Reproduction Point of Male Mojosari Duck (Anas Platyrhynchos) on The Numbers of Spermatogonium Cells and Seminiferous Tubules Diameter
}

\section{Melyandari Ayu Qomar ${ }^{1}$, Rimayanti², and Tri Nurhajati $^{3}$}

${ }^{1}$ Professional Program of Veterinary Medicine, Indonesia

${ }^{2}$ Veterinary Reproduction Department Faculty of Veterinary Medicine, Universitas Airlangga, Indonesia

${ }^{3}$ Veterinary Animal Husbandry Department Faculty of Veterinary Medicine, Universitas Airlangga, Indonesia

\section{Abstract}

Corresponding Author: Melyandari Ayu Qomar

Received: 03 October 2017 Accepted: 10 October 2017 Published: 29 November 2017

Publishing services provided by Knowledge E

(c) Melyandari Ayu Qomar et al. This article is distributed under the terms of the Creative Commons Attribution License, which permits unrestricted use and redistribution provided that the original author and source are credited.

Selection and Peer-review under the responsibility of the VMIC Conference Committee.
The Objective of this research was to know the effect of laserpuncture on reproduction point of male Mojosari duck on the number of spermatogonium cells and seminiferous tubule diameter of the testes. This research using completely randomized design with eighteen male Mojosari ducks which divided into three group randomly. Group I (Po) without any treatment of laserpuncture, Group II (P1) with $0.2 \mathrm{~J}$ dose of laserpuncture, and Group III ( $\left.\mathrm{P}_{2}\right)$ with 0.4 J dose of laserpuncture. Laserpuncture shooting was done on reproduction point with three days interval in one month. On the thirty-first day, the duck was dissected so that the testes can be taken then made by the histological slide of testes. The obtained data processed by Analysis of Variant (ANOVA) followed with Duncan. Research result showed that laserpuncture shoot on the reproduction point of five-month-old male Mojosari duck decreases the number of spermatogonium cells and seminiferous tubule diameter of the testes.

Keywords: laserpuncture, Mojosari duck, spermatogonium, seminiferous tubule.

\section{Introduction}

Duck farming is increasingly desirable as an alternative source of income for rural and urban communities. Because the strategic environment is more favorable to the duck breeding business. The growing market of duck products has contributed to the development of duck farms in Indonesia. Duck egg market that has been formed is still very open for increased production because the existing demand was not all fulfilled, 
though in limited quantities. The main problem of duck breeding in Indonesia so far is the lack of quality seeds, therefore it is necessary to have a breeding business to improve the quality of seeds that are needed to stock market [1]. In the development of livestock, Male duck becomes an important factor because the quality of male duck used determines the quality of the child produced. The quality of reproduction in the male duck is determined by the process of spermatogenesis in the testes [2].

Good reproductivity will lead to significant increases in livestock numbers. One of the things closely related to the increase in the reproducibility of livestock is the quality of sperm. In good goat, sperm quality will produce a high level of conception [3]. The factors that can affect fertility in male animals are environmental factors and management factors used [4]. Needs some effort to fix if the quality of sperm males is not good [3].

One of the ways to improve reproductivity in livestock is by laserpuncture technology. Laserpuncture or laser stimulation is a laser firing at acupuncture points as biological receptors in the body of living things. The use of lasers in livestock aims to improve the biological balance and health of livestock, other benefits are increasing the productivity of livestock and also can improve the reproductive capacity of livestock. One way to achieve that goal is by firing the laser at the points associated with the organ with the goals of health, balance, production, and reproduction in livestock [5].

\section{Materials and methods}

\subsection{Materials}

Eighteen male Mojosari duck 5 months old with 18 in healthy condition, the equipment used in this study is a $20 \mathrm{~mW}$ semiconductor laser. Male Mojosari ducks were randomly divided into three treatment groups, the first group Po without laserpuncture treatment, the second was $P_{1}$ with laserpuncture treatment with a dose of 0.2 Joule and the third $\mathrm{P}_{2}$ with laserpuncture treatment with a dose of 0.4 Joule.

\subsection{Laserpuncture method}

The shooting of the laserpuncture was performed at the point of reproduction for 1 month at three-day intervals. Male Mojosari duck is held in a standing position, then the semiconductor laser is switched on and the laserpuncture shot is aimed at the reproduction point ie the Ova point located in the dorsal region of the last thorax joint with the first lumbar. 
TABLE 1: Spermatogonium cell calculation

\begin{tabular}{|c|c|}
\hline Group & $\begin{array}{c}\text { Spermatogonium cell calculation } \\
\text { (Mean } \pm \text { standard deviation) }\end{array}$ \\
\hline Po & $69.200^{a} \pm 7.70$ \\
\hline P1 & $37.800^{b} \pm 7.10$ \\
\hline P2 & $29.133^{b} \pm 6.54$ \\
\hline
\end{tabular}

\subsection{Spermatogonium cell calculation and diameter of Seminiferous tubules measurement}

Anesthesia and surgery performed on day 31, surgery is done by opening the abdominal cavity and obtained a pair of testes, then testis inserted in containers containing formalin $10 \%$ that have been labeled, then do the preparation of histology. To find out the number of spermatogonium cells and measurement of seminiferous tubular diameter was examined using a microscope with 400x magnification and observed the number of spermatogonium cells. Measurement of the diameter of the seminiferous tubule, the diameter was measured shortest distance. The point is at the boundary between the basal membrane and the spermatogenic cell. Measurements are expressed in units of micrometers.

\section{Results}

Based on statistical analysis it can be seen that firing of laserpuncture at the point of reproduction of male Mojosari duck for 30 days with 3 day time interval shows that group $P_{0}$ is significantly different with group $P_{1}$ and $P_{2}(p<0.05)$. On the other hand, the treatment group $\mathrm{P}_{1}$ was not significantly different from $\mathrm{P}_{2}$ treatment ( $p>0.05$ ).

The histologic changes of spermatogonium cells in male Mojosari ducks observed in this study were spermatogonium cell numbers in seminiferous tubules. Images of each group can be seen in the following figure.

Based on ANOVA test result which continued with Duncan test showed a real difference $(p<0,05)$. The results can be seen that the shooting of laserpuncture at the point of reproduction of male Mojosari duck for 30 days showed that Po was significantly different from $\mathrm{P}_{1}$ and $\mathrm{P}_{2}$ treatment.

The histologic changes of spermatogonium cells in male Mojosari ducks observed in this study were spermatogonium cell numbers in seminiferous tubules. Images of each group can be seen in the following figure. 


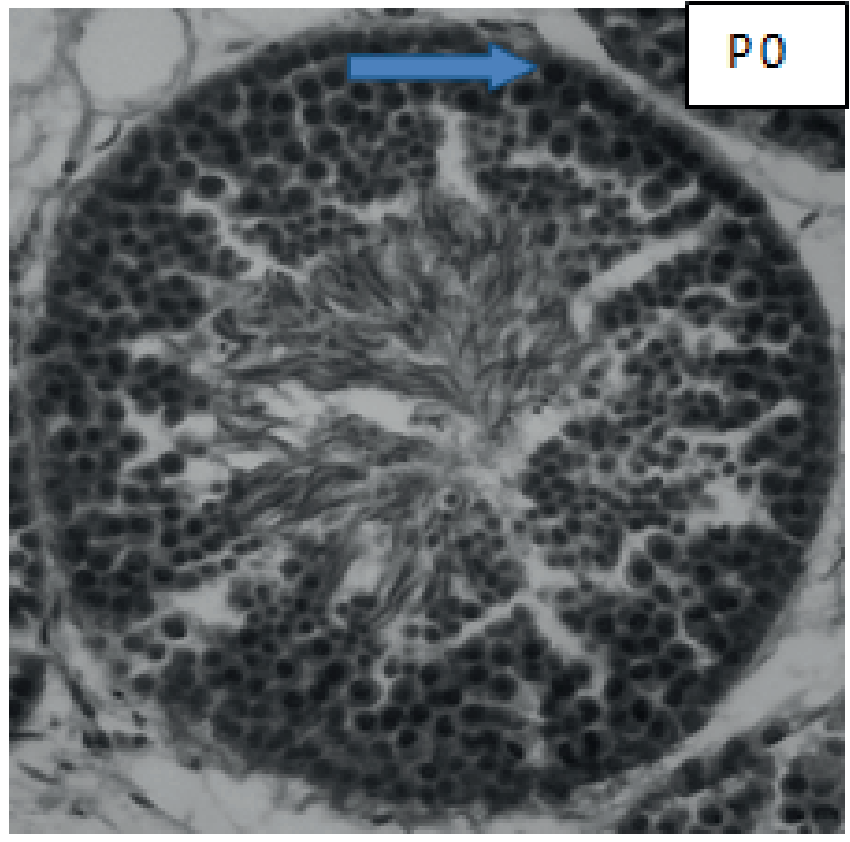

Figure 1: Spermatogonium cells in male Mojosari duck (Po).

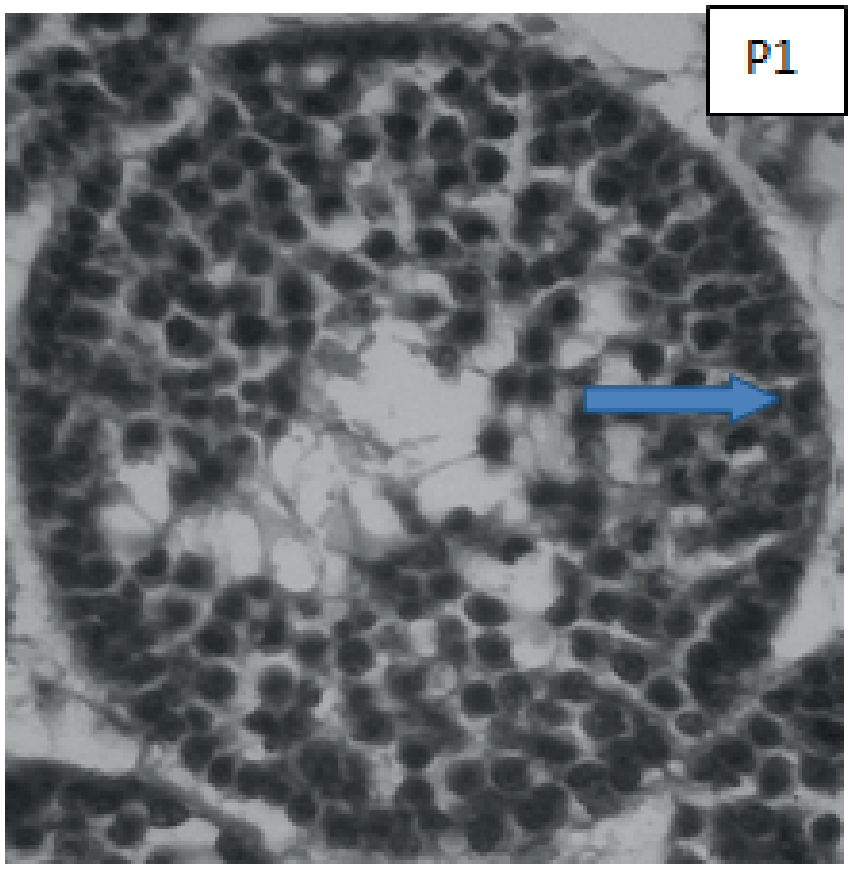

Figure 2: Spermatogonium cells in male Mojosari duck ( $\left.\mathrm{P}_{1}\right)$.

\section{Discussion}

The laserpuncture technology is a technology that utilizes the short wave rays that are fired at biological receptors to enhance the biological capabilities of living things. The laser is a Light Amplificated Stimulated Emission by Radiation. It capable to stimulate 


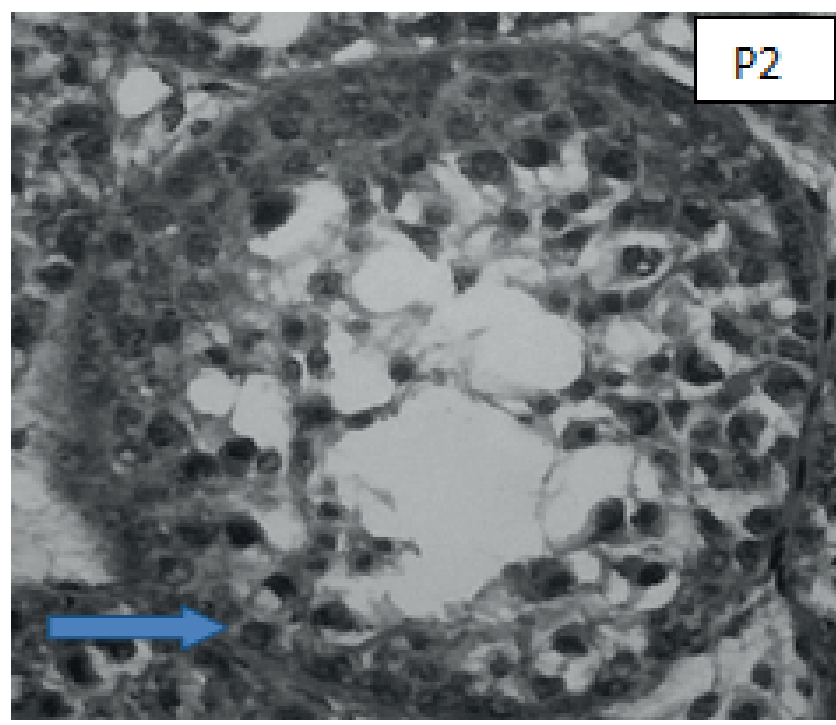

Figure 3: Spermatogonium cells in male Mojosari duck ( $\left.\mathrm{P}_{2}\right)$.

TABLE 2: Diameter of Seminiferous tubules.

\begin{tabular}{|c|c|}
\hline Group & $\begin{array}{c}\text { Diameter of seminiferous tubules } \\
\text { (Mean } \pm \text { standard deviation) }\end{array}$ \\
\hline Po & $150.44^{a} \pm 22.67$ \\
\hline P1 & $104.93^{b} \pm 23.21$ \\
\hline P2 & $101.05^{b} \pm 20.76$ \\
\hline
\end{tabular}

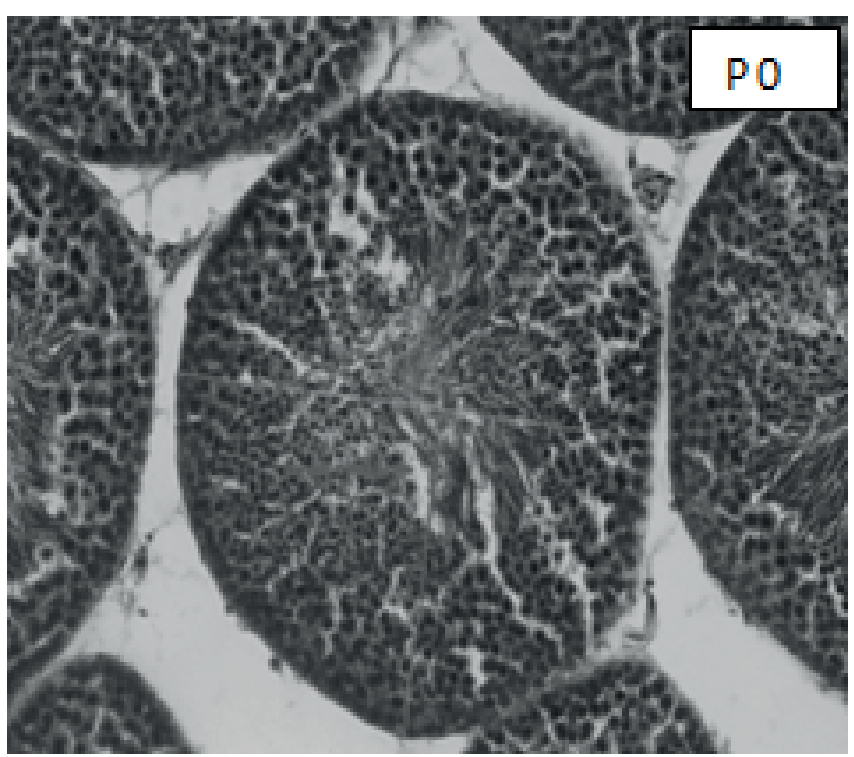

Figure 4: Diameter of spermatogonium cells in male Mojosari duck (Po).

biological receptors resulting in increased capacity and effectiveness of organs [5]. The stimulating mechanism at the acupuncture point begins with an early stimulus in 


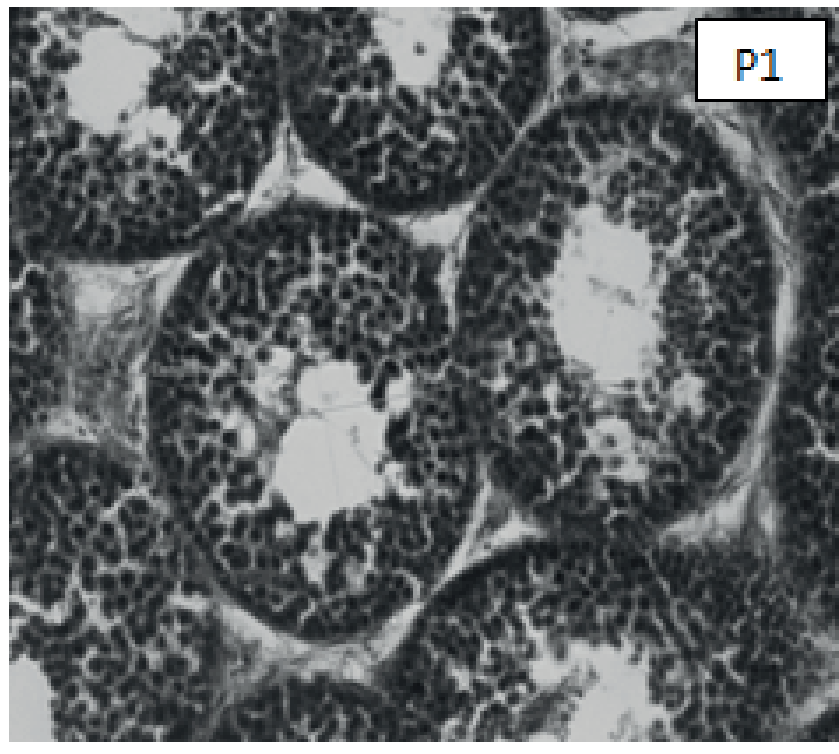

Figure 5: Diameter of spermatogonium cells in male Mojosari duck (P1).

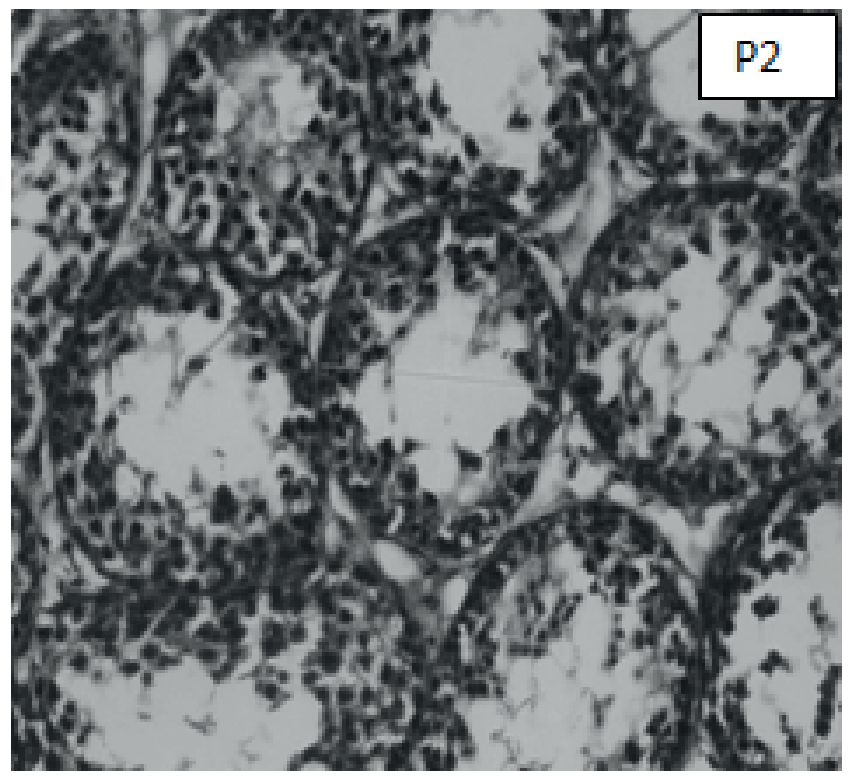

Figure 6: Diameter of spermatogonium cells in male Mojosari duck (P2).

the form of laser shooting at the acupuncture point of the site as a group of electrically active cells will give rise to special activity for the cell collection in the form of membrane depolarization, rRNA stimulation, mRNA activation and protein synthesis process. The specific cellular path connects one acupuncture point to another point so that it reaches the final terminal of the organ [2].

Lasers fired at the point of reproduction of male garut sheep can increase male libido. From that research, it is assumed that laserpuncture firing at the point of reproduction also has the same effect on poultry [2]. In female fowls that are shot using 
laserpuncture at the Ova point can improve female reproductive function [6]. The result of Binawati's research is that laserpuncture shooting in female poultry has a positive effect, so it is suspected that laserpuncture fired in male poultry can give the same effect because the point of Ova in poultry is analogous to the point of GV-4 (ming men) in mammals [5].

The process of acupuncture stimulation in the female reproductive system begins from the point of Ova that stimulates the nerves to the bone marrow and proceeds to the brain, the brain stimulates the hypothalamus to secrete $\mathrm{GnRH}$ which continues stimulation into the ovary. In the male reproductive system, the stimulation is expected to travel towards the testes to stimulate the growth of spermatogonium cells. The hypothalamus functions to secrete GnRH (Gonadotrophin Releasing Hormone) which can stimulate the anterior pituitary gland to secrete Follicle Stimulating Hormone (FSH) Luteinizing Hormone (LH). Both of these hormones play a major role in regulating sexual function in males. FSH is carried through the bloodstream to the testes and initiates the spermatogenesis proliferation process. LH will then complete the process of maturation and formation of spermatozoa. LH secreted by the anterior pituitary gland will be carried through the bloodstream to the testes. In the LH testis it will stimulate interstitial cells to secrete testosterone which is needed for final maturation of spermatozoa. Disorders that occur in the process of secretion and transport of LH and FSH can disrupt the process of spermatogenesis [7].

In this study, the results showed that laserpuncture fired at the point of Ova duck Mojosari males with a dose of 0.2 Joule and 0.4 Joule can reduce the number of spermatogonium cells and diameter seminiferous tubules. So researchers suspect that laserpuncture at the point of ova is a point in female poultry rather than in male poultry. This is suspected because there are compounds or substances that resemble antidote testosterone that has a contradictory with testosterone which can cause decreased testosterone.

Testosterone is a hormone that plays an important role in the development of the male reproductive system, the production of testosterone produced by the testes is influenced by LH and FSH produced by the pituitary gland [8]. When testosterone levels decline there is the possibility of interference in spermatogenesis at the testis seminiferous tubule [9]. Decreases in testosterone levels may have an effect on the structure of the testes such as the diameter of the seminiferous tubules and spermatogenic cells [10].

The decrease of spermatogenic cells in the seminiferous tubules causes the diameter of the seminiferous tubules to be reduced [11]. The decrease in spermatogonium 
cells and shrinking diameter size of seminiferous tubules at doses of 0.2 Joules and 0.4 Joules can be caused by hormonal imbalance from laserpuncture shooting at Ova point or laser stimulation which produces excessive energy. The possibility of energy stimulation obtained by spermatogenic cells is too much to cause spermatogenic cell rupture and decrease testosterone levels. It is possible that testicular size has a correlation with $\mathrm{GnRH}$ and testosterone levels since both increases in testicular size and testosterone production are ultimately under control of GnRH secretion, anything related to testicular size or testosterone production may be due to differences in $\mathrm{GnRH}$ production in Hypothalamus [12].

\section{References}

[1] Prasetyo, L.H., Ketaren, P.P., Setioko, A.R., Suparyanto, A., Juarini, E., Susanti, T., Sopiyana, S. 2010. Panduan Budidaya dan Usaha Ternak Itik.

[2] Herdis. 2010. Aplikasi Teknologi Laserpuncture Dalam Meningkatkan Libido Pejantan Domba Garut (Ovis aries). Pusat Teknologi Produksi Pertanian Deputi Bidang TAB BPPT. Jakarta. Vol. 12 No. 1

[3] Bintara, S. 2011. Rasio Spermatozoa X:Y dan Kualitas Sperma Pada Kambing Kacang dan Peranakan Ettawa. Sains Peternakan Vol.9(2), 65-71

[4] Herdis. 2012. Pengaruh Waktu Penampungan Semen Terhadap Gerakan Massa Spermatozoa dan Tingkah Laku Kopulasi Pejantan Domba Garut. Sains dan Tekknologi Indonesia Vol. 14, no. 1; 38-43

[5] Adikara, RTS. 2001. Teknologi Laserpuncture Pada Ternak. Pusat Penelitian Bioenergi. LKPM Universitas Airlangga.

[6] Binawati, D.A. 2004. Pengaruh Laserpuncture Terhadap Dewasa Kelamin, Produktivitas Telur dan Kualitas Telur Ayam Arab [Thesis]. Fakultas Kedokteran Hewan. Universitas Airlangga.

[7] Prajogo, B. 2007. Pengaruh Daun Justicia Gandarussa Burm f. Terhadap Spermatogenesis Mencit. Jurnal Ilmiah Keluarga Berencana dan Kesehatan Reproduksi. 1-8

[8] Subrata, Tanjung. 2006. Rangsangan Titik Akupunktur Nomer 16 Meningkatkan Kadar Hormon Testosteron Mencit Jantan Usia 9 Bulan. Vol. 1 No. 1

[9] Hafez, E.S.E. 1987. Reproduction In Farm Animal 4 th ed. Lea and Febiger Philadelphia.

[10] Apriliani, M. Nurcahyani, N. dan Busman, H. 2013.Efek Pemaparan Kebisingan Terhadap Jumlah Sel-Sel Spermatogenik dan Diameter Tubulus Seminiferus Mencit (Mus musculus L). Lembaga Penelitian Universitas Lampung. 
[11] Junquiera, L. C., J. Carneiro and R.O. Kelley. 1995. Basic Histology. Appleton and Lange Stanford.

[12] Praseton, B.T, I.R. Stevenson, G.A. Lincoln, S.L.Monfort, J.G. Pilkington and K.Wilson. 2011. Testes Size, Testoterone Production and Reproductive Behaviour in a Natural Mammalian Mating System. Journal of Animal Ecology Vol. 81. 296-305 